\title{
Harvest-aid herbicides influence soybean seed yield, quality and oxidative metabolism
}

\author{
Isabella Sabrina Pereira ${ }^{1,2} \oplus$, Luís Henrique Soares ${ }^{2} \odot$, Ellen Mayara Alves Cabral ${ }^{1} \oplus$, Daniele Cristina Fontana ${ }^{1}$, \\ Renan Caldas Umburanas ${ }^{1,3}{ }^{\mathbb{D}}$, Leandra Larissa Silva Santos ${ }^{2} \mathbb{0}$, Evandro Binotto Fagan ${ }^{2} \mathbb{0}$

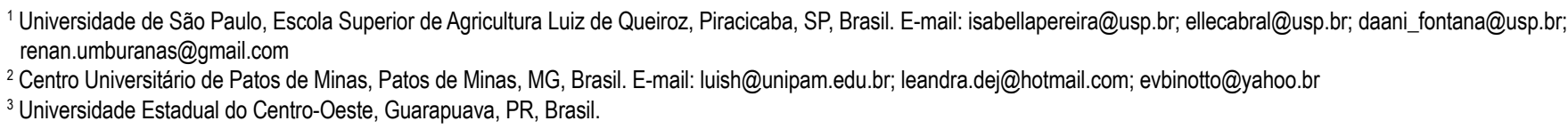

ABSTRACT: Harvest-aid herbicides are used to anticipate soybean harvest and make the field available for next crop during the growing season. However, this anticipation can interrupt the transport of photoassimilates and reduce seed yield, as well as affect the seed quality. It is also not well known if cultivars with earlier growth cycle are more sensitive to harvest-aid herbicides. This work evaluated how different moments of harvest-aid herbicides application affect soybean yield, seed physiological quality, and oxidative metabolism. Two cultivars were used, one early and another medium growth cycle. The herbicide used was paraquat. Experiments were carried out in the field to evaluate yield attributes, and from the seeds harvested, seed quality attributes were evaluated in controlled environment. Early application of harvest-aid herbicides reduced seed yield and 1000-seed mass in both evaluated cultivars, being more expressive for early growth cycle cultivar. Seeds from plants submitted to early application of harvestaid herbicides had higher enzymatic activity related to oxidative metabolism. The early growth cycle cultivar (maturity group - MG 6.2) produced more than the medium growth cycle cultivar (MG 7.7), however, had greater sensitivity to the early application of harvest-aid herbicide.

\section{Herbicidas auxiliares da colheita influenciam a produtividade, qualidade e metabolismo oxidativo de sementes de soja}

RESUMO: Os herbicidas dessecantes são usados para antecipar a colheita de soja, permitindo antecipar a semeadura da próxima cultura durante a estação de cultivo. Contudo, a antecipação da colheita pode interromper o transporte de fotoassimilados e promover redução da produtividade, além de alterar a qualidade das sementes. Há pouca informação se cultivares precoces são mais sensíveis a dessecação antecipada. Este trabalho avaliou como diferentes momentos de dessecação por herbicida afetam a produtividade, a qualidade fisiológica da semente e o metabolismo oxidativo das plântulas derivadas destas sementes. Duas cultivares foram usadas, uma de grupo de maturação precoce e outra média. 0 herbicida utilizado foi 0 paraquat. Experimentos foram conduzidos a campo para avaliar atributos de produtividade, e a partir das sementes colhidas foi conduzido um experimento em ambiente controlado. Dessecação precoce com herbicidas reduziu a produtividade e a massa de mil grãos nas duas cultivares, sendo mais expressivo na cultivar precoce. Sementes oriundas da dessecação precoce têm maior atividade de enzimas do metabolismo oxidativo. A cultivar de ciclo precoce (grupo de maturação - GM 6.2) produziu mais que a cultivar de ciclo médio (GM 7.7), entretanto, teve maior sensibilidade a dessecação antecipada com herbicidas.

Palavras-chave: atividade enzimática; herbicidas-dessecantes; Glycine max L. Merril; peroxidase; superóxido dismutase 


\section{Introduction}

Soybean (Glycine max L. Merrill) is one of the world's leading commodities and its demand grows every year. In the 2017/2018 growing season, 35 million hectares were sowed with soybeans in Brazil, with an average yield of 3,382 kg per hectare (Conab, 2018). Some growers choose to anticipate harvesting through application of harvest-aid herbicides in soybeans, it can homogenize crop maturation and anticipate the sowing of the second crop within the growing season (Pereira et al., 2015).

Harvesting soybean field for seed purposes must be carried out as soon as there is no loss of production and no reduction in the seed physiological quality. Based on the physiological quality of the seeds, the harvest should be performed soon after the period of physiological maturity. However, at this stage the plant still has a high amount of green leaves and green branches, and high-water content in the plant, resulting in difficulties in mechanical harvesting, and may also promote mechanical injury in the seeds.

During physiological maturity, that occurs at phenological stage $R_{7}$, the translocation of photoassimilates from the plant to the seed ceases, and the seeds have the maximum accumulation of biomass, germination and vigor (Fehr \& Caviness, 1977). The moment of the use of harvest-aid herbicide in soybean can impair the quality of the seeds and even disable its use as seed (Sediyama, 2013). This kind of herbicide should be carried out when the remobilization of photoassimilates to the seeds is complete.

Harvest-aid herbicides promotes rapid senescence of the plants, but there is doubt about the impact on the production, germination and vigor of the seeds produced. The delay in the soybean seeds harvesting after physiological maturity is one of the main causes of seed germination and vigor reduction (Sediyama, 2013), and of the greater deterioration of the seeds by the greater wrinkling of the integument and increase of crack percentages due to cycles of wetting and drying that occurs in the field (Marcandalli et al., 2011).

Depending on when it is carried out, soybean harvest-aid herbicide can reduce soybean yield (Toledo et al., 2014), and therefore, performing pre-harvest desiccation at the right time can minimize yield losses. Identifying the ideal phenological stage to perform the desiccation harvest-aid herbicide may be related to the maturity group and the genetic attributes of the cultivar.

There is few information on the effect of harvest-aid herbicide use in soybean seeds quality, and in the resulting seedlings enzymatic activity. This study evaluated the effect of soybean harvest-aid herbicide on yield attributes, harvested seed physiological quality, and attributes of oxidative stress.

\section{Materials and Methods}

Two experiments were carried out, one in field conditions (experiment I) and the other in greenhouse conditions (experiment II), which are described below.

\section{Experiment I}

The soybean field experiment was carried out at 'Rio Paranaíba', Minas Gerais state, Brazil (1921'S, 4607'W, alt. $1195 \mathrm{~m}$ ). The climatic classification of the site is tropical altitude (Cwa), with the average temperature of $20^{\circ} \mathrm{C}$ and annual average rainfall around $1540 \mathrm{~mm}$ (Alvares et al., 2013).

A randomized complete block design was used, consisting of two cultivars, four treatments of plant desiccation, and four replications. The soybean cultivars used were MSoy6210 IPRO with relative maturity group (MG) 6.2 and MSoy7739 IPRO with MG 7.7, both with indeterminate growth habit. The plant desiccation treatments were as follow: natural desiccation at $\mathrm{R}_{8}$ (control), desiccation by harvest-aid herbicide at growth stages $R_{5.3}, R_{5.5}$, and $R_{6}$. Each experimental plot consisted of five rows with $8 \mathrm{~m}$ long and row-spacing of $0.6 \mathrm{~m}$.

Seeding was carried out on November 15, 2016. The seeding rate used was 350,000 and 400,000 plants ha $^{-1}$, for the MG 6.2 and 7.7, respectively. Desiccation by harvest-aid herbicide was performed with the herbicide paraquat $\left(N, N^{\prime}\right.$ dimethyl-4,4'-bipyridinium dichloride) at a dose of 2 I.ha-1, at a concentration of $276 \mathrm{~g}$ of a.i. per liter. $\mathrm{A} \mathrm{CO}_{2}$ propellant sprayer with a pressure of 2 bar was used, and the application volume used was $200 \mathrm{~L} \mathrm{ha}^{-1}$.

An area of $7.2 \mathrm{~m}^{2}$ per plot was harvested at maturity to determine seed yield, seeds per area and 1000-seed mass. Seed moisture was adjusted to $13 \%$.

\section{Experiment II}

It was conducted in a greenhouse, using seed samples harvested from the treatments of experiment I. The treatments were arranged in a randomized block design with four replications. Each replicate consisted of 50 seeds, that were sowed equidistantly in plastic trays, with the following dimensions: $40 \mathrm{~cm}$ long $\times 25 \mathrm{~cm}$ wide and $5.45 \mathrm{~cm}$ deep. The substrate used was washed and sieved medium sand. Seeding was performed 20 days after harvest and seedling evaluations were performed 15 days after sowing. The dry biomass of the stem, leaves and cotyledons were determined, and five seedlings were used per replication. The seedling biomass was subjected to air drying at $65^{\circ} \mathrm{C}$ during $48 \mathrm{~h}$.

The antioxidant enzymes activity was evaluated at 15 days after sowing. Samples of the fresh leaf biomass were ground, and $200 \mathrm{mg}$ were macerated with $4 \mathrm{~mL}$ of $0.1 \mathrm{~mol}$ $\mathrm{L}^{-1}$ potassium phosphate buffer $\mathrm{pH}$ 6.8. Then, samples were transferred to Eppendorf flasks, and centrifuged at 10,000 rpm for $30 \mathrm{~min}$ at $4{ }^{\circ} \mathrm{C}$ (Kar \& Mishra, 1976). Finally, samples were stored at -20 o $C$ until determinations of leaf protein content (Bradford, 1976), superoxide dismutase enzyme (Beauchamp \& Fridovich, 1971), and peroxidase enzyme activity (Teisseire \& Guy, 2000).

\section{Statistical analysis}

The data were submitted to the Shapiro-Wilk test and, when the normality assumption was fulfilled, the analysis of variance was performed and, when significant, the averages 
were classified by the Tukey test at $5 \%$ significance, through the statistical program $\mathrm{R}$ (version 3.0).

\section{Results}

\section{Analysis of variance}

There was interaction between treatments for seed yield, 1000 -seed mass, and superoxide dismutase enzyme activity. Between cultivars there was difference for leaf biomass, cotyledons biomass, and the enzyme peroxidase. Among desiccation treatments there was difference for resulting seedlings stem, leaf and cotyledon biomass (Table 1 ).

\section{Experiment I}

The seed yield of the cultivar MSoy6210 was higher than the cultivar MSoy7739 at the desiccation times $R_{5.5}, R_{6}$ and $R_{8}$, except for the $R_{5.3}$ stage where no difference was found between cultivars. For the cultivar MSoy6210 the seed yield reduced by $55.9,20.6$ and $10 \%$ due desiccation by herbicide at $R_{5.3}, R_{5.5}$ and $\mathrm{R}_{8}$ growth stages, respectively. For the cultivar M-SOY 7739 the seed yield reduced by 29.2, 19.9 and $16.5 \%$, due desiccation by herbicide at $R_{5.3}, R_{5.5}$ and $R_{8}$ growth stages, respectively. Within the desiccation treatments, in $\mathrm{R}_{5.3}$ the yield of the cultivar MSoy7739 was $20.5 \%$ higher than the cultivar MSoy6210, however in $R_{5.5}$, $\mathrm{R}_{6}$ and in control treatment, the yield of the cultivar MSoy6210 were $32,43.6$, and 33.2\% higher, respectively. (Figure $1 \mathrm{~A}$ ).

The 1000-seed mass for the cultivar MSoy6210 reduced by 25.9, 15 and $2.86 \%$ due desiccation by herbicide the $R_{5.3}, R_{5.5}$ and $R_{8}$ growth stages, respectively. For the cultivar MSoy7739 the 1000 -seed mass reduced by $22.2,14.2$ and $1.35 \%$, due desiccation by herbicide the $R_{5.3}, R_{5.5}$ and $R_{8}$ growth stages, respectively. Within the desiccation treatments, the 1000 seed mass of MSoy6210 was 6.0, 10.7, 10.1, and $11.0 \%$ higher than cultivar MSoy7739 at $R_{5.3}, R_{5.5}, R_{6}$, and $R_{8}$ growth stages, respectively (Figure 1B).

\section{Experiment II}

The leaf biomass was higher in control $\left(R_{8}\right)$ treatment, and all the treatments derived from seeds from plants submitted to desiccation by herbicide reduced leaf biomass in soybean seedlings. Leaf biomass 1.3 times higher in cultivar MSoy7739 than cultivar MSoy6210 (Figure 2). The cotyledon biomass was higher in control and early burndown at $R_{6}$. The cotyledons biomass was 1.2 times higher in cultivar MSoy7739 than in cultivar MSoy6210 (Figure 2).

The stem biomass decreased by $34 \%$ in desiccation by herbicide at the $R_{5.3}$ stage in relation to the control. The stem biomass was 1.2 times higher in the MSoy7739 compared to the cultivar MSoy6210 (Figure 2).

The peroxidase activity was 1.2 times higher in the cultivar MSoy7739 than in the cultivar MSoy6210 (Figure 3). The enzyme superoxide dismutase had higher activity in the cultivar MSoy7739 at desiccation by herbicide at $R_{5.3}$ and $R_{5.5}$. The enzymatic activity of the super oxide dismutase in the desiccation by herbicide at $\mathrm{R}_{6}$ and in the control, did not differ between the cultivars. The enzymatic activity of superoxide dismutase in cultivar MSoy6210 did not differ between desiccation treatments (Figure 3).

Table 1. Significance of the analysis of variance of the evaluated attributes: yield, 1000-seed mass (1000-SM), peroxidase (POD), superoxide dismutase (SOD), stem biomass, leaf biomass, and cotyledons biomass (Cot).

\begin{tabular}{cccccccc}
\hline & Yield & 1000-SM & POD & SOD & Stem & Leaf & Cot \\
\hline Cultivar (cv) & $* *$ & $* *$ & $* *$ & $* *$ & ns & $* *$ & $* *$ \\
Moment (m) & $* *$ & $* *$ & ns & $*$ & $* *$ & $* *$ & ns \\
cv x m & $* *$ & $* *$ & $\mathrm{~ns}$ & $* *$ & $\mathrm{~ns}$ & $\mathrm{~ns}$ \\
\hline
\end{tabular}

$*^{*}, *$, and ns were significant at $p<0.01, p<0.05$ and non-significant, respectively, by the $\mathrm{F}$-test at $5 \%$ probability.

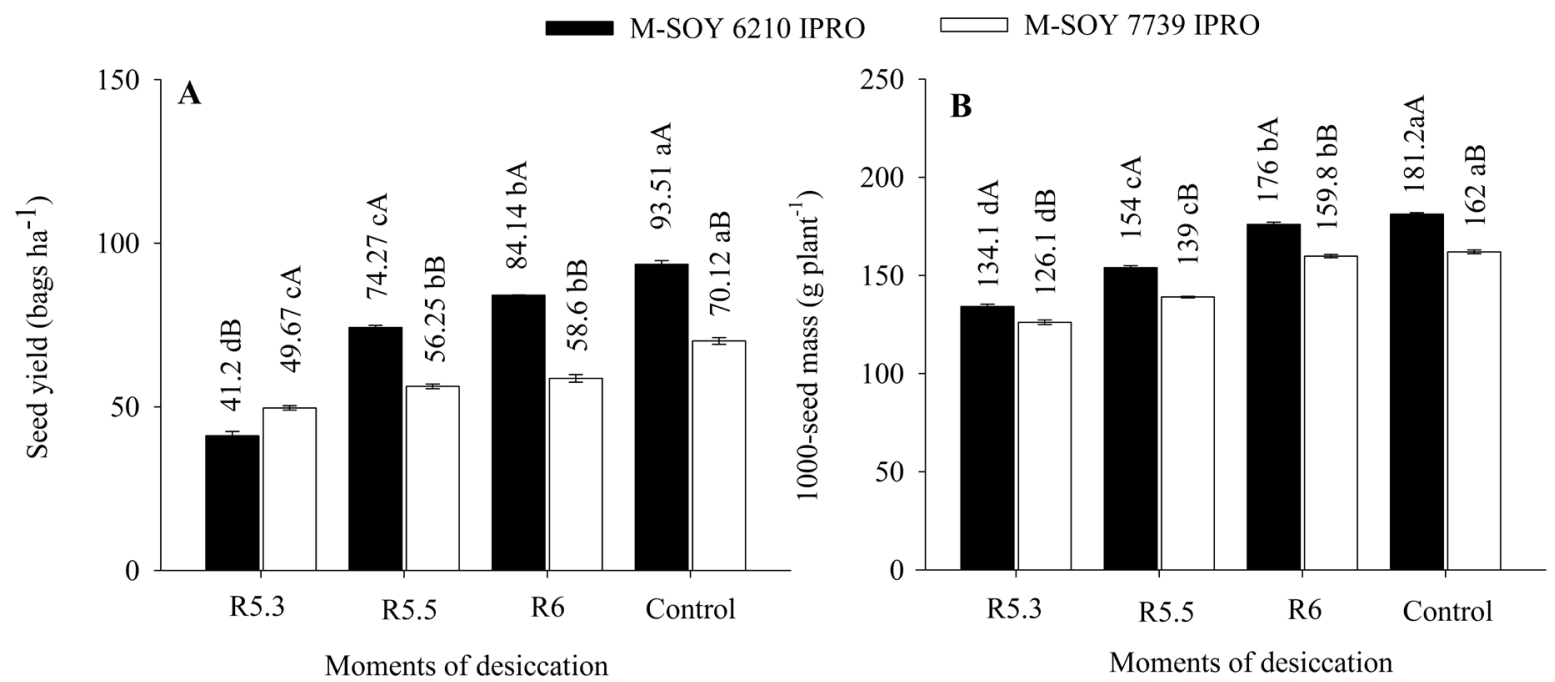

* Means followed by the same letter, lowercase between desiccation treatments and upper case between cultivars did not differ by Tukey test at $5 \%$ significance.

Figure 1. Seed yield (A) and 1000-seed mass (B) of soybean cultivars at different moments of desiccation by herbicides at Rio Paranaiba, Minas Gerais, Brazil. 

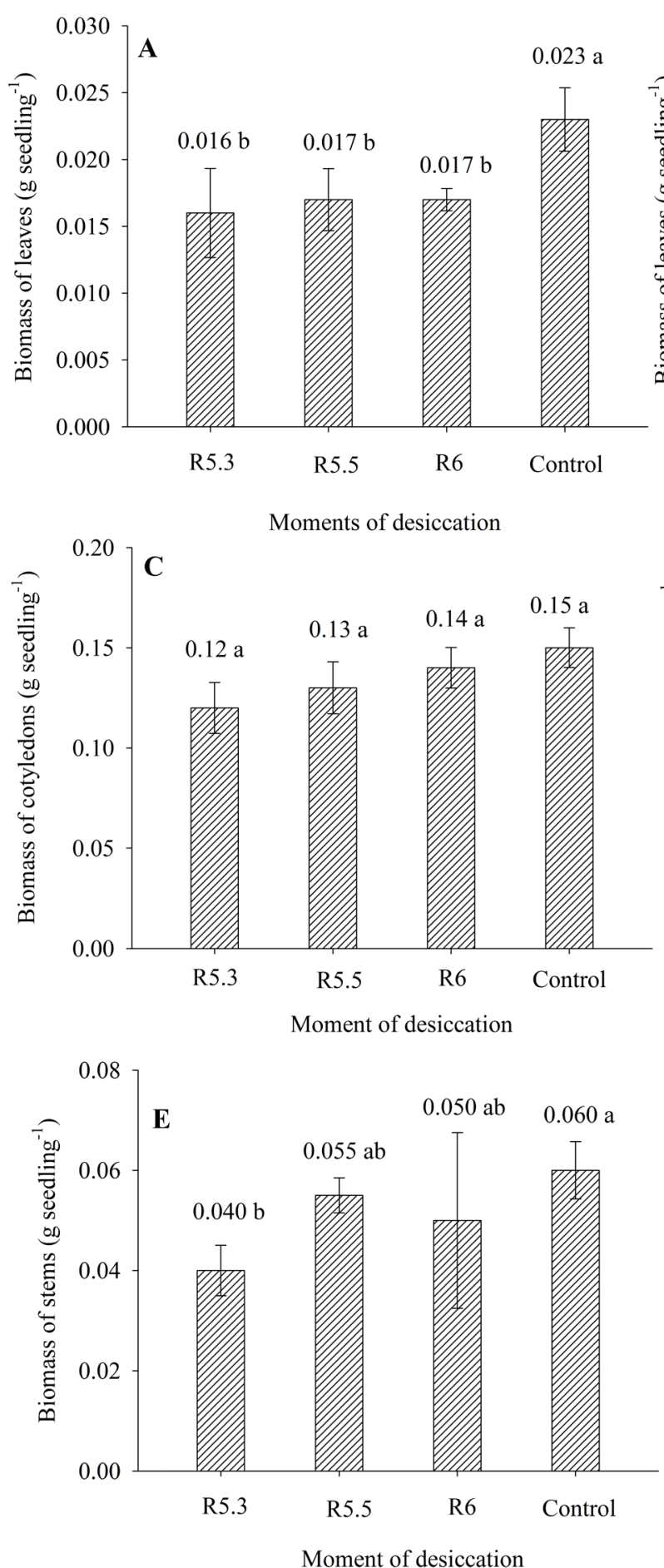

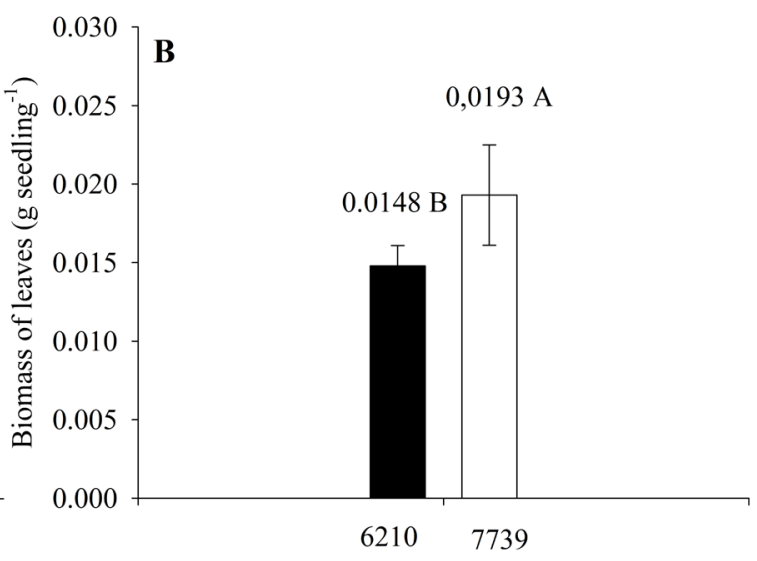

Soybean cultivar

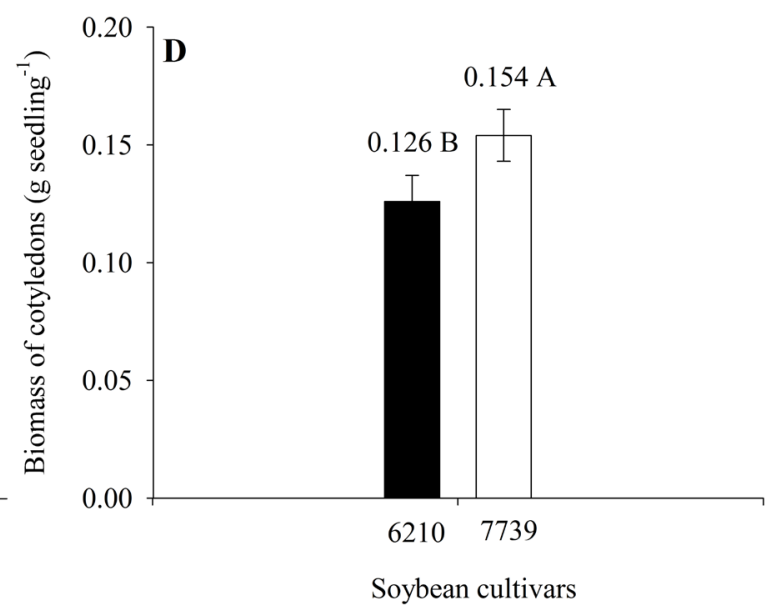

* Means followed by the same letter, lowercase between desiccation treatments and upper case between cultivars did not differ by Tukey test at $5 \%$ significance.

Figure 2. Biomass of leaves ( $A$ and $B$ ), biomass of cotyledons ( $C$ and $D)$, and biomass of stems $(E)$ by the moments of desiccation or by the cultivar in soybean seedlings.

\section{Discussion}

Desiccation by harvest-aid herbicides at $R_{5.3}, R_{5.5}$ and $R_{6}$ on soybean cultivars MSoy6210 and MSoy7739 reduced yield, 1000-seed mass, biomass. As well as increased activity of oxidative metabolism enzymes POD and SOD. The shortcycle cultivar MSoy6210 was more sensitive to the anticipated desiccation, and this fact may be related to the lower accumulation of biomass in the seeds, when compared to the medium-cycle cultivar that had greater biomass accumulation in the seeds. The higher biomass accumulation in the medium cycle cultivar MSoy7739 corroborated with the higher enzymatic activity of POD and SOD in this cultivar.

In another study, the desiccation by herbicide performed at the $R_{5.3}$ and $R_{5.5}$ stages for the cultivar Valiosa RR reduced seed mass, resulting that these growth stages are not the appropriate for desiccation (Finoto et al., 2017). When the desiccation is performed at this time, the plant is not at its 


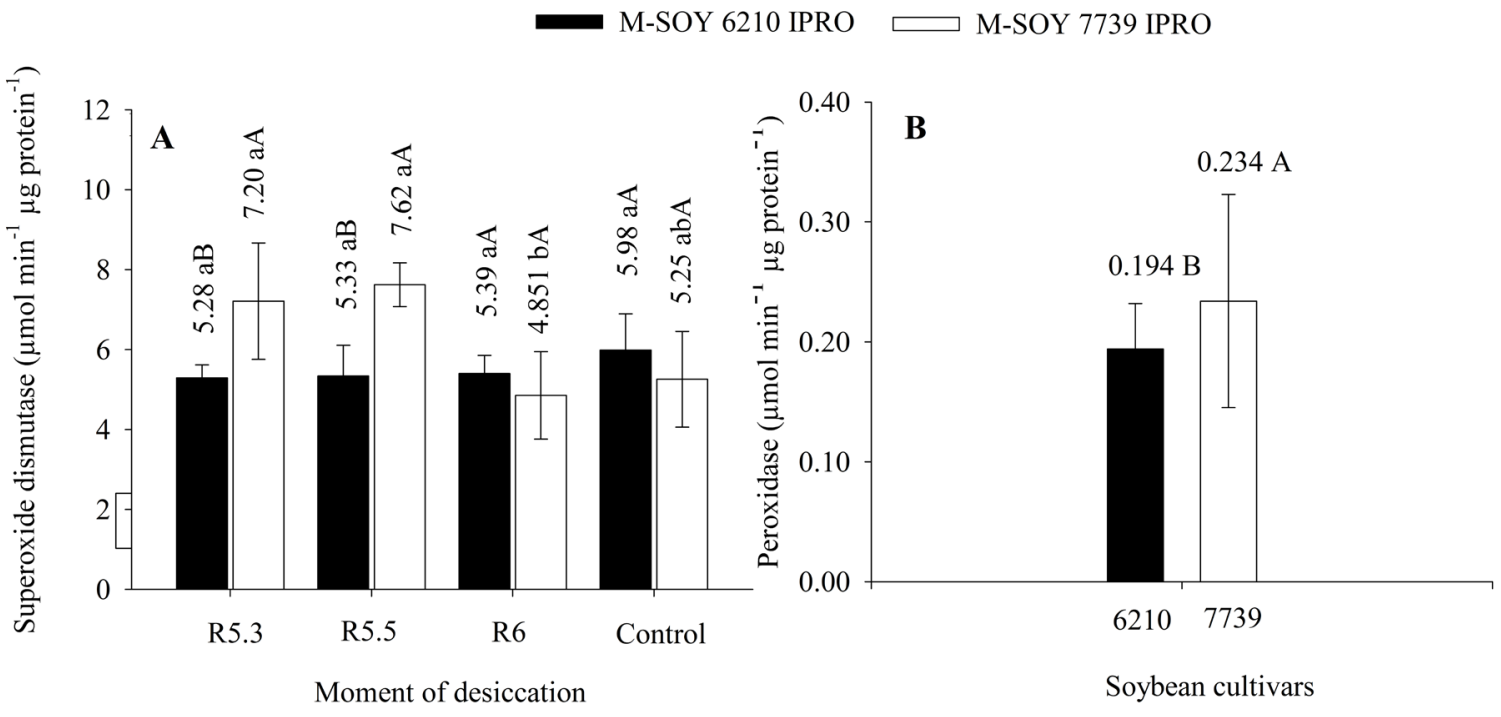

*Means followed by the same letter, lowercase between desiccation moments and upper case between cultivars did not differ by Tukey test at $5 \%$ significance.

Figure 3. Enzymatic activity of superoxide dismutase (A) and peroxidase (B) in soybean seedlings derived from seeds from different desiccation treatments and cultivars.

physiological maturity, i.e. the seed is still in the filling stage. The premature plant death results in the seeds photoassimilates accumulation interruption (Carvalho \& Nakagawa, 2000). The earlier the desiccation by herbicide in soybean plants, the greater the losses in seed mass (Kappes et al., 2009).

Soybeans seeds obtained from plants submitted to desiccation by herbicides at $R_{6}$ growth stage are of physiological quality inferior to those obtained with application in the stages $R_{7}$ and $R_{8}$ (Marcandalli et al., 2011). The desiccation at $R_{7}$ growth stage in the 'Conquista' cultivar reduced root length, hypocotyl length, total length and total dry biomass of soybean seedlings when compared to treatment without desiccation (Toledo et al., 2014).

Early desiccation can raise the seed electrical conductivity, i.e. it may affect the integrity of the membranes, reduce their physiological quality, the seed vigor, and are more sensitive to storage (Botelho et al., 2016).

The pre-harvest desiccation with paraquat herbicide increased the germination in soybean seeds from cultivar BRS Candeia at the $R_{6}$ stage $(92 \%)$, when compared to $R_{7}(79 \%)$ and $R_{8}(71 \%)$, however, desiccation at the $R_{6}$ stage reduced seed yield when compared to later stages (Peluzio et al., 2008).

Although the plant desiccation at the $R_{6}$ and $R_{7}$ growth stages with the herbicide paraquat increase the germination rate, the vigor of the seeds derived from the desiccation at the $R_{6}$ stage is lower (Lamego et al., 2013). If soybean seeds contain a large amount of water content during harvest-aid herbicide application, it can damage seed cells due herbicide translocation into the cells (Botelho et al., 2019).

The pre-harvest desiccation performed at the $\mathrm{R}_{7}$ stage with paraquat increased seed yield and anticipated the harvest in six days. Plants without desiccation by herbicides stay longer in the field, the pods become more susceptible to dehiscence and adverse conditions, and consequently can reduce yield (Pereira et al., 2015) and seed quality.
Early plant desiccation performed with paraquat at the $R_{7.3}$ stage increases or maintains seed quality and can anticipate harvesting in two days compared to control (Kappes et al., 2009).

The desiccation by herbicide at $R_{8}$ may be useful when the soybean field does not have uniform maturation or have plants with green stem disorder (Harbach et al., 2016).

Seeds originating from desiccation by herbicide at $R_{7.1}$ and $R_{7.3}$ did not reduce the germination rate (Finoto et al., 2017). Plant desiccation by herbicide carried out from the $\mathrm{R}_{7}$ phenological stage does not reduce yield, however, plant desiccation by herbicide performed prior to this period can reduce yield (Pereira et al., 2015).

Seeds of the cultivar MSoy7739 from plants desiccated by herbicides at $R_{5.3}$ and $R_{5.5}$ originated seedlings with higher activity of peroxidase enzymes. This presented that preharvest desiccation impaired the physiological, biochemical and enzymatic quality of the seeds.

The desiccation by herbicides anticipated stage $R_{6}$, or earlier, reduces activity of the POD enzyme, reduces seed yield and seed vigor, evidencing that it should not be a management practice for seed production.

The enzyme peroxidase is related to processes of lignification metabolism, auxin formation, salt stress tolerance and heavy metal tolerance (Passardi et al., 2005). This enzyme has been used as a metabolic attribute related to growth and responsiveness to environmental stress.

Increased activity of antioxidant enzymes is considered a mechanism of adaptation to stress (Bargaz et al., 2015). The higher activity of these enzymes is associated with the reduction of oxidative damage and the improvement of plant tolerance to stressors (Kibria et al., 2017).

The medium-cycle cultivar had higher enzymatic production of SOD and POD than the short-cycle cultivar, which evidences genetic difference in this attribute. The higher production of 
enzymatic compounds in seeds from early desiccation may be associated to a biochemical imbalance in seed formation. This results in an activation of stress enzymes in the development of the embryo and the formation of seedlings from these seeds.

Soybean yield is directly related to the photosynthesis performed by the leaves, the remobilization, and duration of the seed filling (Li et al., 2006). The early plant desiccation reduced the seed-filling period, resulting in lower yield. Medium-cycle cultivars may have longer duration of the reproductive period as well as longer duration of seed filling, thus resulting in higher 1000-seed mass, and seedlings derived from these seeds with greater vigor.

At $R_{5}$ the soybean plants begin the seed filling, at any of the four upper nodes. At the $R_{6}$ stage the total seed filling in the pods occurs, with physiological maturity occurring at the $R_{7}$ stage, and is characterized by the presence of a mature brown pod at any node of the main stem (Fehr \& Caviness, 1977).

Also, at $R_{5}$ the plant reaches the highest photosynthetic rate and higher biological fixation rate (Herridge \& Peoples, 2002), because the demand for photoassimilates by the seed drain is very high. The soybean seed usually begins to deteriorate from its physiological maturity $\left(R_{7}\right)$ when it already has germination capacity (Wang et al., 2007).

In the physiological maturation there is a greater accumulation of dry matter, and from this phase, only water loss occurs. Thus, from the $\mathrm{R}_{7}$ growth stage, there are no yield losses in biomass accumulation (Sediyama et al., 2015).

The low performance of seeds from early desiccation soybean plants may be related to the fact that the plant is still translocating photoassimilates into the seed, resulting in premature seed formation (Peluzio et al., 2008).

\section{Conclusion}

Anticipated burndown by herbicide reduced seed yield and 1000 -seed mass in both cultivars, especially the cultivar MSoy6210, in the same way increased antioxidants enzymes activity.

The early-cycle cultivar MSoy6210 (GM 6.2) yielded more than the medium-cycle cultivar MSoy7739 (GM 7.7), however the first was more impaired by anticipation burndown by herbicide.

\section{Literature Cited}

Alvares, C.A.; Stape, J.L.; Sentelhas, P.C.; Gonçalves, J.L.M.; Sparovek, G. Köppen's climate classification map for Brazil. Meteorologische Zeitschirift, v.22, n.6, p.711-728, 2013. https:// doi.org/10.1127/0941-2948/2013/0507.

Bargaz, A.; Zaman-Allah, M.; Farissi, M.; Lazali, M.; Drevon, J.J.; Maougal, R.T.; Georg, C. Physiological and molecular aspects of tolerance to environmental constraints in grain and forage legumes. International Journal of Molecular Sciences., v.16, n.8, p.18976-19008, 2015. https://doi.org/10.3390/ijms160818976.
Beauchamp, C.H.; Fridovich, I. Superoxide dismutase improved assays and an assay applicable to acrylamide gels. Analytical Biochemistry, v.44, n.1, p.276-287, 1971. https://doi. org/10.1016/0003-2697(71)90370-8.

Botelho, F.J.E.; Oliveira, J.A.; Von Pinho, E.V.D.R.; Carvalho, E.R.; Figueiredo, Í.B.D.; Andrade, V. Quality of seeds of soybean obtained from different cultivars subjected to desiccation with different herbicides and application times (abstract in English, text in Portuguese). Revista Agro@mbiente On-line, v.10, n.2, p.137-144, 2016. https://doi.org/10.18227/1982-8470ragro. v10i2.2760.

Botelho, F.J.E.; Oliveira, J.A.; Von Pinho, E.V.D.R.; Carvalho, E.R., Resende, M.P.M.; Reis, L.V. Quality of soybean seeds with different lignin content obtained from desiccated plants. Revista Brasileira de Ciências Agrárias, v.14, n.3, p.5674, 2019. https:// doi.org/10.5039/agraria.v14i3a5674.

Bradford, M.M. A rapid and sensitive method for quantification of microgran quantities of protein utilizing the principle of proteindye-binding. Analytical Biochemistry, v.72, n.1-2, p.248-254, 1976. https://doi.org/10.1016/0003-2697(76)90527-3.

Carvalho, N.M.; Nakagawa, J. Sementes: ciência, tecnologia e produção. 4.ed. Campinas: Fundação Cargill, 2000. 588 p.

Companhia Nacional de Abastecimento - Conab. Acompanhamento da safra brasileira de grãos: monitoramento agrícola safra 2017/2018. Brasília: Conab, 2018. v. 5, n. 5. 140p.https://www. conab.gov.br/info-agro/safras/graos/boletim-da-safra-de-graos/ item/download/12569_5b3e0e675171f49a5b1e9215edc1064a. 15 Mar. 2019.

Fehr, W.R.; Caviness, C.E. Stages of soybean development. Ames: lowa State University; Agricultural and Home Economics Experiment Station, 1977. 80p. (Special Report, 87). https://lib. dr.iastate.edu/specialreports/87. 10 Mar. 2019.

Finoto, E.L.; Sediyama, T.; Albuquerque, J.A.A.; Soares, M.B.B.; Galli, J.A.; Cordeiro Junior, P.S.; Menezes, P.H.S. Antecipação e retardamento de colheita nos teores de óleo e proteína das sementes de soja, cultivar Valiosa RR. Scientia Agropecuária, v.8, n.2, p.99-107, 2017. https://doi.org/10.17268/sci. agropecu.2017.02.02.

Harbach, C.; Chawla, S.; Bowen, C.R.; Hill, C.B.; Nafziger, E.D.; Hartman, G.L. Association of green stem disorder with agronomic traits in soybean. Agronomy Journal, v.108, n.6, p.2263-2268, 2016. https://doi.org/10. 213 4/ag ronj2016.03.0155.

Herridge, D.F.; Peoples, M.B. Timing of xylem sampling for ureide analysis of nitrogen fixation. Plant and Soil, v.238, n.1, p.57-67, 2002. https://doi.org/10.1023/A:1014292328435.

Kappes, C.; Carvalho, M.A.C.; Yamashita, O.M. Potencial fisiológico de sementes de soja dessecadas com diquat e paraquat. Scientia Agraria, v.10, n.1, p.1-6, 2009. https://doi.org/10.5380/rsa. v10i1.12520

Kar, M.; Mishra, D. Catalase, peroxidase, and polyphenol oxidase activities during rice leaf senescence. Plant Physiology, v.57, n.2, p.315-319, 1976. https://doi.org/10.1104/pp.57.2.315.

Kibria, M.G.; Hossain, M.; Murata, Y.; Hoque, M.A. Antioxidant defense mechanisms of salinity tolerance in rice genotypes. Rice Science, v.24, n.3, p.155-162, 2017. https://doi.org/10.1016/j. rsci.2017.05.001. 
Lamego, F.P.; Gallon, M.; Basso, C.J.; Kulczynski, S.M.; Ruchel, Q.; Kaspary, T.E.; Santi, A.L. Dessecação pré-colheita e efeitos sobre a produtividade e qualidade fisiológica de sementes de soja. Planta Daninha, v.31, n.1, p.929-938, 2013. https://doi.org/10.1590/ S0100-83582013000400019.

Li, X.; An, P.; Inanaga, S.; Eneji, A.E.; Tanabe, K. Salinity and defoliation effects on soybean growth. Journal of plant nutrition, v.29, n.8, p.1499-1508, 2006. https://doi. org/10.1080/01904160600837642.

Marcandalli, L.H.; Lazarini, E.; Malaspina, I.C. Épocas de aplicação de dessecantes na cultura da soja: qualidade fisiológica de sementes. Revista Brasileira de Sementes, v.33, n.2, p.241-250, 2011. https://doi.org/10.1590/S0101-31222011000200006.

Passardi, F.; Cosio, C.; Penel, C.; Dunand, C. Peroxidases have more functions than a Swiss army knife. Plant Cell Reports, v.24, n.5, p.255-265, 2005. https://doi.org/10.1007/s00299-005-0972-6.

Peluzio, J.M.; Ramo, L.N.; Fidelis, R.R.; Afférri, F.S.; de Castro-Neto, M.D.; Correia, M.A.R. Influência da dessecação química e retardamento de colheita na qualidade fisiológica de sementes de soja no sul do estado do Tocantins. Bioscience Journal, v.24, n.2, p.77-82, 2008. http://www.seer.ufu.br/index.php/ biosciencejournal/article/view/6996. 19 Mar. 2019.
Pereira, T.; Coelho, C.M.M.; Souza, C.A.; Mantovani, A.; Mathias, V. Dessecação química para antecipação de colheita em cultivares de soja. Semina: Ciências Agrárias, v.36, n.4, p.2383-2394, 2015. https://doi.org/10.5433/1679-0359.2015v36n4p2383.

Sediyama, T. Tecnologia e Produção de Sementes de soja. Londrina: Mecenas, 2013. 352 p.

Sediyama, T.; Silva, F.L.; Borém, A. Soja do plantio a colheita. Viçosa: UFV, 2015. $333 \mathrm{p}$.

Teisseire, H.; Guy, V. Copper-induced changes in antioxidant enzymes activities in fronds of duckweed (Lemna minor). Plant Science, v.153, n.1, p.65-72, 2000. https://doi.org/10.1016/S01689452(99)00257-5.

Toledo, M.Z.; Sayuri Ishizuka, M.; Cavariani, C.; de Barros FrançaNeto, J.; Bilia Picoli, L. Pre-harvest desiccation with glyphosate and quality of stored soybean seeds. Semina: Ciências Agrárias, v.35, n.2, 2014. https://doi.org/10.5433/16790359.2014v35n2p765.

Wang, F.; Wang, L.Q.; Tian, X.; Gu, W.H.; Ma, H. Pre-harvest and post-harvest seed deterioration resistance of spring soybean germplasm in south China. Scientia Agricultura Sinica, v.40, n.11, p.2637-2647, 2007. http://www.chinaagrisci.com/EN/Y2007/ V40/I11/2637\#1. 29 Mar. 2019. 